\title{
PENGEMBANGAN ASSESSMENT PERILAKU PROKRASTINASI AKADEMIK MAHASISWA BIDIKMISI
}

\author{
Zainal Arifin ${ }^{1}$, Awang Roni Effendi ${ }^{2}$ \\ ${ }^{1,2}$ Program Studi Penjaskesrek, Fakultas Pendidikan Olahraga dan Kesehatan, \\ IKIP PGRI Pontianak, Jln. Ampera No. 88 Pontianak \\ 1e-mail: zai_inal@yahoo.co.id
}

\begin{abstract}
Abstrak
Prokrastinasi akademik merupakan perilaku menunda-nunda mengerjakan ataupun menyelesaikan tugas-tugas akademik. Penelitian ini bertujuan memberikan gambaran mengenai prokrastinasi akademik yang dialami oleh mahasiswa bidikmisi program studi pendidikan jasmani kesehatan dan rekreasi IKIP PGRI Pontianak yakni sejumlah 26 orang. Penelitian ini menggunakan metode Research and Development yakni melakukan pengembangan assesment prokastinasi akademik mahasiswa. Penelitian ini menggunakan alat pengumpul data berupa angket validasi kelayakan para ahli serta angket prokastinasi akademik mahasiswa. Analisis data dalam penelitian ini menggunakan teknik persentase. Hasil yang diperoleh dalam penelitian ini berupa validasi assessment prokrastinasi akademik mahasiswa dengan kategori layak serta menggambarkan kondisi prokrastinasi akademik mahasiswa pada kategori sangat tinggi terjadi pada aspek kemalasan dengan kontribusi sebesar $46.12 \%$ sebanyak 12 orang mahasiswa. Dalam penelitian ini prokrastinasi akademik yang dialami oleh mahasiswa dikategorikan dalam beberapa aspek antara lain keyakinan akan kemampuan, gangguan perhatian, faktor sosial, manajemen waktu, inisiatif, pribadi, dan kemalasan.
\end{abstract}

Kata kunci: prokrastinasi akademik, behaviour, tugas akademik

\begin{abstract}
Academic procrastination is the behavior of procrastinating or completing academic tasks. This study aims to provide an overview of the academic procrastination experienced by Bidikmisi students in the Health and Recreation Education Study Program of IKIP PGRI Pontianak, which is 26 people. This research uses the Research and Development method, which is to develop a student academic assessment assessment. This study uses a data collection tool in the form of a questionnaire validation of the feasibility of experts and a student academic procrastination questionnaire. Data analysis in this study used percentage techniques. The results obtained in this study in the form of validation of the assessment of academic procrastination of students in the proper category and illustrate the conditions of student academic procrastination in the very high category occurred in the aspect of laziness with a contribution of $46.12 \%$ as many as 12 students. In this research, academic procrastination experienced by students is categorized in several aspects, including belief in ability, attention disturbances, social factors, time management, initiative, personal, and laziness.
\end{abstract}

Keywords: academic procrastination, behavior, academic assignments

\section{PENDAHULUAN}

Mahasiswa adalah peserta didik yang terdaftar dan belajar di setiap satuan Pendidikan Perguruan Tinggi. Mahasiswa dalam tahap perkembangannya digolongkan pada masa remaja. Hurlock (1980: 206) menjelaskan bahwa awal 
masa remaja berlangsung kira-kira dari 13-17 tahun. Pada masa perkembangannya, mahasiswa selayaknya perlu dibimbing agar terbentuknya diri secara positif serta memiliki kemandirian dan pengendalian diri dalam memecahkan satu permasalahan yang dialaminya.

Sebagai seorang mahasiswa, belajar merupakan kewajiban yang harus dipenuhi. mahasiswa dituntut untuk memiliki pengelolaan belajar yang baik, khususnya dalam pengelolaan waktu. Pengelolaan waktu belajar yang kurang baik menyebabkan mahasiswa melakukan penundaan dalam mengerjakan tugas-tugas akademik. Perilaku menunda tugas-tugas akademik disebut dengan prokrastinasi akademik.

Burka \& Yuen (2004: 9) mendefinisikan prokrastinasi adalah "To defer action, delay; to put of till another day or time". Prokrastinasi merupakan kebiasaan tindakan dalam menunda tugas sampai hari lain. Rothblum, dkk (dalam Ngoc, 2007:198), menjelaskan bahwa "Academic procrastination the focus of the present study can be considered the delay of tasks specifically related to studying, working, or completing academic assignments". Fokus prokrastinasi akademik saat ini dapat dianggap penundaan tugas khusus yang berkaitan dengan belajar atau menyelesaikan tugas-tugas akademik.

Seung, dkk (2012: 12) menjelaskan bahwa "Procrastination has been commonly understood as a maladaptive behavior that impedes successful academic experiences". Penundaan umumnya dipahami sebagai perilaku maladaptif yang dapat menghambat sukses akademik. Prokrastinasi dapat berupa respon tetap dalam mengantisipasi tugas- tugas yang tidak disukai dan dipandang bisa diselesaikan dengan sukses. Prokrastinasi akademik merupakan kegagalan dalam mengerjakan tugas dalam jangka waktu yang diinginkan atau menunda mengerjakan tugas sampai saat-saat terakhir.

Individu yang tidak mampu menyelesaikan tugasnya dengan tepat waktu disebabkan individu tersebut terlalu fokus kepada nilai standar yang ditetapkan dan terlalu banyak berfikir tentang bagaimana orang lain menilai tugas individu tersebut. Sehingga terdapat hubungan antara perfeksionisme dengan prokrastinasi akademik. Penundaan dikaitkan dengan kebiasaan mahasiswa sekarang ini, 
penundaan juga menyebabkan mahasiswa sering mengalami keterlambatan dalam mempelajari akademiknya serta terlambat untuk menyusun suatu karya atau laporan, mengumpulkan tugas-tugas menjelang tenggat waktu yang telah di tentukan, mengembalikan buku-buku perpustakaan, terlambat mendaftar ujian, dan sebagainya, selanjutnya seringnya melewatkan kelas itu juga salah satu penyebab mahasiswa yang suka menunda-nunda (Rosario, et al, 2009: 17) serta dari penundaan tersebut dapat menimbulkan konflik dengan orang tua atau temanteman (Rosario, et al, 2009: 18). Dalam hal ini mahasiswa yang sering menundanunda segala sesuatunya lebih sering muncul perselisihan dengan orang tua karena mahasiswa tersebut tidak dapat mengerjakan tugas rumah dengan baik dan tepat waktu, kemudian mahasiswa yang sering melakukan penundaan dapat menimbulkan kesalahpahaman antar teman-temannya karena jika mengerjakan tugas secara kelompok biasanya individu tersebut tidak dapat memaksimalkan hasil pengerjaannya secara sempurna dan tepat waktu.

Pengamatan peneliti pada mahasiswa bidikmisi Program Studi Penjaskesrek dapat disimpulkan bahwa kebiasaan menunda-nunda tugas yang tidak bertujuan merupakan hal yang biasa dilakukan. Hal ini diperkuat oleh keterangan dari beberapa dosen yang menyatakan bahwa seakan sudah menjadi fenomena kebiasaan menunda-nunda tugas merupakan hal yang lazim dilakukan. Sebagian mahasiswa menunda mengerjakan tugas serta aktivitas lain yang lebih menyenangkan. Sehingga mahasiswa biasa mengerjakan tugas sebelum bel masuk atau mengerjakannya disela-sela mata pelajaran lain.

Program bidikmisi adalah program beasiswa bagi mahasiswa yang memiliki kemampuan akademiknya baik tetapi berasal dari keluarga yang tidak mampu. kemajuan yang diperoleh dalam program pengajaran, pada waktu yang lebih cepat atau usia yang lebih muda. (kemenristekdikti, 2019: 30).

Dikatakan bahwa mahasiswa yang memperoleh bidikmisi adalah anak yang lebih mampu menguasai dan mengintegrasikan bahan-bahan pelajaran yang kompleks. Mahasiswa bidikmisi memiliki kemampuan untuk belajar dan mengingat kembali sejumlah besar informasi dengan cepat, mengolah informasi dengan efektif, berdisiplin tinggi, dan selalu sukses untuk tugas-tugas yang 
melibatkan analisis logis. Mahasiswa bidikmisi bisa saja memenuhi kualifikasi secara akademis namun secara sosial, fisik dan emosional masih kurang matang. Secara emosional mahasiswa bidikmisi mungkin saja akan merasa frustasi dengan adanya tekanan dan tuntutan yang ada, dimana mereka dituntut harus memperoleh nilai indeks prestasi kumulatif (IPK) serendah-rendahnya adalah 3,00, hal ini juga dapat memicu stress pada diri mahasiswa.

Munculnya prokrastinasi akademik dalam diri mahasiswa bidikmisi diprediksi tidak terjadi begitu saja, namun terdapat penyebab yang melatarbelakangi. Menurut Ferrari, Johnson, \& Mc Cown (1995) dalam Muyana (2018: 48) menyebutkan bahwa penyebab perilaku prokrastinasi adalah; 1) Adanya pikiran irrasional dari prokrastinator, yaitu anggapan bahwa suatu tugas harus diselesaikan dengan sempurna; 2) Adanya kecemasan karena kemampuannya dievaluasi, ketakutan akan kegagalan dan susah mengambil keputusan, atau karena membutuhkan bantuan orang lain untuk mengerjakan tugasnya; 3) Malas dan kesulitan mengatur waktu dan tidak menyukai tugasnya; 4) Adanya punishment dan reward juga dapat menyebabkan prokrastinasi sehingga merasa lebih aman jika tidak melakukan dengan segera karena dapat menghasilkan sesuatu yang tidak maksimal; 5) Adanya faktor lingkungan, yaitu kurangnya pengamatan dari lingkungan seperti keluarga atau di lingkungan sekolah juga menyebabkan seseorang melakukan prokrastinasi; 6) Selain itu prokrastinasi disebabkan karena tugas yang menumpuk, terlalu banyak dan harus segera dikerjakan, sehingga penundaan tugas yang satu dapat menyebabkan tugas lain tertunda.

Pada penelitian ini peneliti akan merancang asessment perilaku prokrastinasi akademik dari masiswa bidikmisi program studi penjaskes sebagai upaya untuk mengetahui permasalahan yang dihadapi mereka dalam proses perkuliahan.

\section{METODE}

Metode penelitian yang digunakan dalam penelitian ini adalah Research and Development (R\&D). Penelitian dan pengembangan atau Research and 
Development (R\&D) adalah sebuah strategi atau metode penelitian yang cukup ampuh memperbaiki praktik (Sukmadinata, 2006: 44). Penelitian dan pengembangan merupakan suatu proses atau langkah-langkah untuk mengembangkan suatu produk baru atau menyempurnakan produk yang telah ada dan dapat dipertanggungjawabkan. Produk tersebut dapat berupa perangkat keras ataupun perangkat lunak. Perangkat keras misalnya buku, modul, alat bantu pembelajaran di kelas atau di laboratorium. Perangkat lunak meliputi program komputer pengolahan data, pembelajaran di kelas, perpustakaan atau laboratorium, model-model pendidikan, pembelajaran, pelatihan, bimbingan, evaluasi, manajemen, dan lain-lain.

Model pengembangan yang digunakan dalam pengembangan bahan ajar ini adalah Hannafin \& Peck Model, yang merupakan salah satu model desain pembelajaran sistematik. Romiszowski (1996: 38) mengemukakan bahwa pada tingkat desain materi pembelajaran dan pengembangan, sistematik sebagai aspek prosedural pendekatan sistem telah diwujudkan dalam banyak praktik metodologi untuk desain dan pengembangan teks, materi audiovisual, dan materi pembelajaran berbasis komputer. Pemilihan model ini didasari atas pertimbangan bahwa model ini dikembangkan secara sistematis dan berpijak pada landasan teoretis desain pembelajaran.

Hannafin and Peck model berfokus pada pemecahan masalah kendala kualitas dan kompleksitas pengembangan yang terdiri dari tiga tahapan yakni; 1) penilaian kebutuhan; 2) tahap desain; dan 3) pengembangan dan evaluasi, dimana ketiga tahapan terhubung pada kegiatan "evaluasi dan revisi" yang merupakan tahap yang sangat penting dalam penyempurnaan produk (Tegeh, 2014: 27).

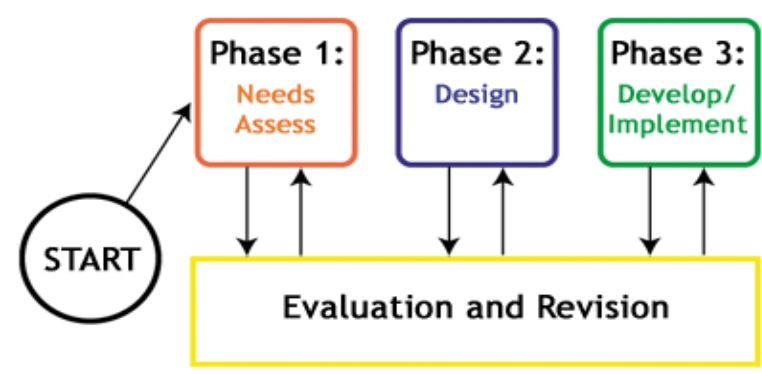

\section{Gambar 1 Tahapan Model Pengembangan Hannafin dan Peck}


Sesuai dengan tujuan penelitian yang telah dikemukakan, maka subjek penelitian merupakan mahasiswa beasiswa bidikmisi Program Studi Penjaskesrek yang terdiri dari 19 orang mahasiswa, 5 mahasiswa angkatan 2016, 5 mahasiswa angkatan 2017, 3 mahasiswa angkatan 2018, dan 6 mahasiswa angkatan 2019.

Teknik pengumpulan data yang digunakan dalam penelitian ini adalah teknik komunikasi tidak langsung. Adapun alat pengumpul data yang digunakan adalah Angket validasi ahli serta angket respon guru yang dibuat berdasarkan skala Likert.

Data dianalisis secara deskriptif menggunakan teknik persentase menurut David dan Cholik (Ridwan, 2014: 27). Dengan kriteria interprestasi kelayakan dan respon sebagai berikut.

Tabel 1 Kriteria Interpretasi Penilaian Validator

\begin{tabular}{cc}
\hline Persentase & Kriteria \\
\hline $0 \%-20 \%$ & Sangat Tidak Layak \\
$21 \%-40 \%$ & Kurang Layak \\
$41 \%-60 \%$ & Cukup \\
$61 \%-80 \%$ & Layak \\
$81 \%-100 \%$ & Sangat Layak \\
\hline
\end{tabular}

Pengembangan instrumen dianalisis menggunakan analisis data kualitatif Miles and Hubberman. Menurut Miles and Hubermen (Sugiyono, 2016: 337) dalam menganalisis data kualitatif dilakukan secara interaktif dan berlangsung terus-menerus hingga tuntas.

\section{HASIL DAN PEMBAHASAN}

Hasil validasi kelayakan produk asessment perilaku prokastinasi Akademik bertujuan untuk mengetahui apakah produk penelitian yang dikembangkan siap untuk di ujicobakan, Tabel 2 menyajikan hasil rekapitulasi validasi kelayakan oleh tim ahli. 
Tabel 2 Validasi Kelayakan Asessment Perilaku Prokastinasi Akademik

\begin{tabular}{lcc}
\hline \multirow{2}{*}{ Kriteria } & \multicolumn{2}{c}{ Penilaian } \\
\cline { 2 - 3 } & Ahli 1 & Ahli 2 \\
\hline 1. Kelayakan isi & $73 \%$ & $80 \%$ \\
2. Kelayakan penyajian & $75 \%$ & $80 \%$ \\
3.Penilaian bahasa & $80 \%$ & $76 \%$ \\
4.Penilaian eksperimen & $80 \%$ & $80 \%$ \\
\hline \multicolumn{1}{c}{ Rata-rata Total Nilai } & $77 \%$ & $79 \%$ \\
\hline
\end{tabular}

Berdasarkan penilaian dari tim ahli, diperoleh data dari kelayakan isi ahli pertama memberikan penilaian $73 \%$, ahli kedua $80 \%$, kelayakan penyajian ahli pertama $75 \%$ dan ahli kedua $80 \%$, penilaian Bahasa ahli pertama $80 \%$ dan ahli kedua $76 \%$ dan untuk penilaian eksperimen ahli pertama $80 \%$ dan ahli kedua $80 \%$.

Setelah memperoleh hasil penilaian para ahli tersebut, selanjutnya dilakukan revisi agar produk lebih baik dari sebelumnya dan dapat diujicobakan di lapangan. Perbaikan dilakukan berdasarkan penilaian dan saran oleh tim ahli.

Berikut disajikan data profil prokrastinasi akademik mahasiswa bidikmisi, dapat dilihat pada Tabel 3.

Tabel 3 Persentase Profil Prokastinasi Akademik Mahasiswa Bidikmisi

\begin{tabular}{|c|c|c|c|c|c|c|c|c|c|c|c|c|}
\hline \multirow[t]{2}{*}{ Kategori } & \multicolumn{2}{|c|}{$\begin{array}{c}\text { Keyakinan } \\
\text { akan } \\
\text { kemampuan }\end{array}$} & \multicolumn{2}{|c|}{$\begin{array}{l}\text { Gangguan } \\
\text { Perhatian }\end{array}$} & \multicolumn{2}{|c|}{$\begin{array}{l}\text { Faktor } \\
\text { Sosial }\end{array}$} & \multicolumn{2}{|c|}{$\begin{array}{c}\text { Manajemen } \\
\text { Waktu }\end{array}$} & \multicolumn{2}{|c|}{$\begin{array}{l}\text { Inisiatif } \\
\text { Pribadi }\end{array}$} & \multicolumn{2}{|c|}{ Kemalasan } \\
\hline & $\mathrm{f}$ & $\%$ & $\mathrm{f}$ & $\%$ & $\mathrm{f}$ & $\%$ & $\mathrm{f}$ & $\%$ & $\mathrm{f}$ & $\%$ & $f$ & $\%$ \\
\hline $\begin{array}{l}\text { Sangat } \\
\text { Tinggi }\end{array}$ & 10 & 38.46 & 5 & 19.23 & 12 & 46.15 & 11 & 42.31 & 9 & 34.62 & 6 & 23.08 \\
\hline Tinggi & 10 & 38.46 & 9 & 34.62 & 8 & 30.77 & 6 & 23.08 & 9 & 34.62 & 12 & 46.15 \\
\hline Rendah & 4 & 15.39 & 7 & 26.92 & 5 & 19.32 & 3 & 11.54 & 5 & 19.23 & 7 & 26.92 \\
\hline $\begin{array}{l}\text { Sangat } \\
\text { Rendah }\end{array}$ & 2 & 7.69 & 2 & 7.69 & 1 & 3.85 & 6 & 23.08 & 3 & 11.54 & 1 & 3.85 \\
\hline
\end{tabular}


Berdasarkan Tabel 3 di atas kondisi prokrastinasi akademik yang berdasar jumlah mahasiswa dengan skor persentase pada masing-masing indikator prokrastinasi akademik. Pertama, pada indikator keyakinan akan kemampuan memiliki persentase tertinggi pada kategori sangat tinggi sebesar 38,46\% dan tinggi juga sebesar 38,46\%. Kedua, pada indikator gangguan perhatian memiliki persentase tertinggi pada kategori tinggi yakni sebesar 34,62\%. Ketiga, pada indikator faktor sosial memiliki persentase tertinggi pada kategori sangat tinggi yaitu sebesar 46,15\%. Keempat, pada indikator manajemen waktu memiliki persentase tertinggi pada kategori sangat tinggi sebesar 42,31\%. Kelima, pada indikator inisiatif pribadi memiliki persentase tertinggi pada kategori sangat tinggi yakni 34,62\% dan kategori tinggi 34,62\%. Keenam, pada indikator terakhir yaitu indikator kemalasan memiliki kategori persentase tertinggi pada kategori tinggi sebesar $46,15 \%$.

Berdasarkan deskripsi data di atas, dapat dilakukan pembahasan berdasarkan perolehan data sebagai berikut, bahwa keyakinan akan kemampuan mahasiswa bidikmisi terlihat memperoleh persentase yang sangat tinggi dan tinggi kontribusi terjadinya prokrastinasi akademik, salah satu faktornya disebabkan oleh beban akademik yang harus mereka jalankan untuk bisa mencapai target sebagai mahasiswa bidikmisi. Hal ini senada dengan yang disampaikan oleh Ghufron (2010: 16) bahwa prokastinasi akademik bisa timbul karena seseorang merasa takut gagal dalam mengerjakan tugas serta kesalahan dalam mengerjakan tugas, sehingga membuat seseorang menjadi cemas, karena seseorang ingin selalu benar dalam mengerjakan tugasnya.

Gangguan perhatian juga tergolong memiliki persentase yang tinggi dalam kontribusi terjadinya prokrastinasi akademik, hal ini disebabkan oleh pemusatan akan perhatian mahasiswa bidik misi terhadap suatu pembelajaran membutuhkan konsentrasi penuh, karena apabila tidak maka akan memunculkan kesulitan bagi mereka untuk mencapai target yang telah ditetapkan, tetapi munculnya gangguangangguan dari berbagai faktor, baik faktor secara internal ataupun eksternal pada akhirnya dapat mengganggu konsentrasi yang telah mereka bangun sedari awal perkuliahan. Hal ini sejalan dengan yang dikatakan oleh Ferrari (1995) bahwa 
munculnya perilaku prokrastinasi akademik ini ditunjang oleh beberapa faktor yang kondusif untuk menjadi katalisator munculnya perilaku prokrastinasi akademik pada seseorang yaitu faktor internal, yaitu faktor yang ada dalam diri individu yang meliputi faktor fisik dan psikologis dan faktor eksternal berupa faktor di luar diri individu berupa gaya pengasuhan dan kondisi lingkungan yang linier.

Faktor sosial memiliki dampak yang tinggi dalam kontribusi terjadinya prokrastinasi akademik ini terlihat dari besarnya persentase jumlah mahasiswa yang mengalaminya, hal ini salah satunya disebabkan oleh ketidakmampuan mahasiswa dalam bersosialisasi dan berkomunikasi ketika menjalani kehidupan di kampus dan dilingkungan tempat tinggalnya.

Manajemen waktu juga memiliki jumlah persentase yang sangat tinggi sebagai penyumbang kontribusi terjadinya prokastinasi akademik, hal ini cenderung disebabkan oleh belum terbiasanya mahasiswa akan jadwal serta tugastugas perkuliahan yang diberikan oleh dosen sehingga membuat mereka tidak disiplin dalam mengelola waktu mereka.

Inisiatif pribadi secara persentase memperoleh jumlah yang sangat tinggi dan tinggi dalam kontribusi terjadinya prokastinasi akademik, hal ini disebabkan oleh mahasiswa belum terbiasa dengan pengambilan keputusan-keputusan dalam menjalani perkuliahan serta kehidupannya di perantauan, sehingga mereka tidak mampu untuk mengambil sebuah inisiatif pribadi dalam memutuskan sesuatu yang benar tanpa harus diberi tahu oleh orang lain.

Kemalasan pada kategori tinggi memperoleh persentase jumlah yang besar sebagai penyebab terjadinya prokastinasi akademik, hal ini disebabkan oleh mahasiswa tidak ingin atau belum termotivasi untuk melakukan apapun termasuk menyelesaikan tugas-tugas akademik sehingga terjadi penumpukan tanggung jawab yang harus mereka selesaikan pada satu waktun yang bersamaan, Rosario (2009: 20) berpendapat bahwa prokastinasi akademik dapat timbul dikarenakan mahasiswa yang sering menunda-nunda segala sesuatunya lebih sering muncul perselisihan dengan orang tua karena mahasiswa tersebut tidak dapat mengerjakan tugas rumah dengan baik dan tepat waktu, kemudian mahasiswa yang sering 
melakukan penundaan dapat menimbulkan kesalahfahaman antar teman-temannya karena jika mengerjakan tugas secara kelompok biasanya individu tersebut tidak dapat memaksimalkan hasil pengerjaannya secara sempurna dan tepat waktu.

\section{SIMPULAN}

Berdasarkan hasil penelitian dan pembahasan, secara umum dapat disimpulkan bahwa (1) Hasil penilaian para ahli menyatakan bahwa Asessment Prokastinasi akademik mahasiswa berkategori layak, (2) Pada indikator keyakinan akan kemampuan memiliki persentase tertinggi pada kategori sangat tinggi sebesar 38,46\% dan tinggi juga sebesar 38,46\%, pada indikator gangguan perhatian memiliki persentase tertinggi pada kategori tinggi yakni sebesar $34,62 \%$, pada indikator faktor sosial memiliki persentase tertinggi pada kategori sangat tinggi yaitu sebesar 46,15\%, pada indikator manajemen waktu memiliki persentase tertinggi pada kategori sangat tinggi sebesar 42,31\%. Kelima, pada indikator inisiatif pribadi memiliki persentase tertinggi pada kategori sangat tinggi yakni $34,62 \%$ dan kategori tinggi 34,62\%, pada indikator kemalasan memiliki kategori persentase tertinggi pada kategori tinggi sebesar 46,15\%.

\section{DAFTAR PUSTAKA}

Burka, J., B., \& Lenora, M. Yuen. (2008). Procrastination: why you do it, what to do about it now. America: Da Capo Press.

Ferrari, J. R. Judith L, Johnson, William, G. McCown. (1995). Procrastination and task avoidance, theory, research and treathment. New York: Plenum Press.

Ghufron, M.N., \& Rini, R. (2010). Teori-teori psikologi. Yogyakarta: Ar-Ruzz Media.

Hurlock, E. B. (1980). Psikologi perkembangan: suatu pendekatan sepanjang rentang kehidupan. Terjemahan oleh Soedjarwo. Jakarta: Erlangga.

Kemenristekdikti. (2019). Panduan Pendaftaran Beasiswa Bidikmisi. Ditjen Belmawa Kemenristekdikti.

Muyana, S. 2018. Prokrastinasi akademik dikalangan mahasiswa program studi bimbingan konseling. jurnal bimbingan dan konseling, 8 (1), 45-52.

Ngoc, H. Bui. (2007). Effect of evaluation threat on procrastination behavior. the journal of social psychology, 147 (3).

Ridwan. (2014). Dasar-dasar statistika. Bandung: Alfabeta Press. 
Romiszowski, A. J. (1996). System approach to design and development. in plomp, t. \& ely, d.p. (editor in chiefs). International Encyclopedia of Educational Technology. Oxford: Pergamon Press.

Rosario, Pedro, Costa, M., dkk. (2009). Academic procrastination: Associations with personal, school, and family variables. Journal Of Psychology, 12, (1), 118-127.

Seung \& Rayne, A., Park, W., Sperling. (2012). Academic Procrastinators and Their Self-Regulation. Journal Psychology, 3 (1).

Sugiyono. (2016). Metode penelitian dan pengembangan. Bandung: Alfabeta.

Sukmadinata, S., N. (2006). Metode penelitian pendidikan. Bandung: PT. Remaja Rosdakarya.

Tegeh, dkk. 2014. Model penelitian dan pengembangan. Bali: Graha Ilmu. 